\title{
SOCIO-STRUCTURAL INNOVATIONS IN INDONESIA'S URBAN SUFISM The Case Study of the Majelis Dzikir and Shalawat Nurul Mustafa
}

\author{
Arif Zamhari \\ UIN Maulana Malik Ibrahim, Malang - Indonesia
}

\begin{abstract}
Sufi tradition has grown significantly in the modern Muslim world, including Indonesia. Currently, Sufism has been not only practiced by villagers, peasants, and non-educated people, but also practiced by urbanites, national elites, and educated people. Moreover, it has experienced significant innovation in terms of its practices and organization. This article takes an in-depth look at the innovationof Sufi tradition socially and structurally in Indonesia. It argues that majelis drikir and shalawat in Indonesia, like Nurul Mustafa, has represented a new Sufi group that arises out of tarekat group, a group that has been considered as 'official institution' in implementing Sufism. The Majelis Nurul Mustafa has strong basis in urban society, rises from urban majelis taklim, introduces Sufi teaching to its jamä ah that mostly urban teenagers and youths uses popular methods to attract the interest of those groups to attend its ritual as the complementary of its activity.
\end{abstract}

Keywords: Urban Sufism, majelis drikir, majelis shalawat, majelis taklim.

\section{Introduction}

Social scientists and Islamists have predicted that the Sufi tradition as well as its proponents will diminish in the Muslim world following the development of Muslim society toward shariah oriented community. ${ }^{1}$ Moreover, according to them, Sufi traditions will become

\footnotetext{
1 Julia Day Howell, "Sufism and the Indonesian Islamic Revival," The Journal of Asian Studies, 60, 3 (2001), pp.701-729.
} 
the remnant of Muslim history when Muslim has adopted the values of modern society socially and economically and when modern reformation of Islamic society has taken place. In the course of the history of Sufism in Indonesian, Sufi traditions have also experienced marginalization among modernist Muslims for several decades². However, the prediction has proved to be flawed. Even though Sufi tradition has been strongly challenged by modernist Muslim in the last few decades, it has grown significantly in the Muslim world including Indonesia, the most populous Muslim majority country in the world. Sufism has been not only practiced by villagers, peasants, and uneducated people, but also has been practiced by urbanites, national elites, and educated people. Even, modernist Muslims, who once were strongly opposed to Sufi traditions due to its heretical elements, have practiced Sufism and joined tarekat group.

Moreover, during the last few decades Sufi tradition in both Indonesian urban and rural area has experienced significant innovation in terms of its practices and organization ${ }^{3}$. Previously, Sufism only can be practiced through numerous organized Sufi groups (tarekat), for now in order to practice Sufi ritual, Indonesian Muslims need not join a particular structured Sufi order (tarekat) formally with its complicated rules. People can practice drikir ritual as widely practiced in the tarekat groups without necessarily being members of the tarekat. New majelis dzikir and majelis shalawat have been emerging in urban and rural areas. Instead of tarekat, these new groups serve as an alternative venue for Muslims to improve their spiritual lives.

Majelis dzikir and shalawat have proliferated over the last few decades not only in urban areas but also in rural areas. Without a doubt, the locus of the majelis drikir and majelis shalawat activities especially in the rural areas has been pesantren (Islamic boarding schools). Pesantren have played a pivotal role not just in Islamic education generally, but also in maintaining Sufi tradition in Indonesia. The pesantren through their leaders and alumni networks have been disseminating majelis drikir and shalawat throughout Indonesia. Recently

2 Julia Day Howell, "Modernity and Islamic Spirituality in Indonesia's new Sufi Networks," in Martin Van Bruinessen and Julia Day Howell, (eds). Sufism and The Modern' in Islam (New York and London: IB Tauris, 2007), p. 217.

${ }^{3}$ Arif Zamhari, Rituals of Islamic Spirituality: A Study of Majelis Dhiker Groups in East Java (Canberra: ANU E-press, 2010). 
they have spread to urban areas, which is the focus of our current research project.

In urban areas another institution has been important in facilitating the proliferation of majelis dzikir and shalawat is the majelis taklim. The majelis taklim also grew out of the pesantren, but have sprung up independently both in rural and urban areas. They now play an important role in preaching and teaching Islam to urbanites. In the last ten years the majelis taklim in urban areas functioned not only as centres for lectures on Islam (pengajian umum) but also as centers for activities known as majelis drikir and shalawat, ritual practices commonly conducted by Sufi groups especially the tarekat or Sufi orders. This study examines the emergence of majelis taklim as a locus for drikir and shalawat activities as well as a centre for Islamic preaching (da wah Islamiyah) among urbanites.

Despite the importance of majelis taklim in urban areas, there has been scant attention to the study of the contemporary practices of drikir and shalawat conducted by majelis taklim in urban areas. Moreover, in the study of urban Sufism, little attention has been given to the proliferation of dzikir and shalawat practices among urbanites as part of the development of neo Sufi tradition in Indonesia. In addition, as widely held among Indonesian Muslims, the popular practices of drikir and shalawat proliferated in the last few decades cannot be regarded as part of Sufi practices that has been practised by tarekat groups. I spent almost nine months among majelis drikir and shalawat groups in Jakarta, following from one of drikir and shalawat ritual to another ritual held by the group, recording its teachings and ceremonies, collecting its literature and interviewing the member of the majelis from the leader (kyai and habib), teachers (al-asatidb) to the followers of the majelis.

It is hoped that this study will contribute to the understanding of spiritual life of urbanites. In urban areas which have been known for their secular orientation, majelis taklim have provided space for people to deeply experience a new way of encountering in Sufi tradition. Documenting the recent growth of majelis dzikir and shalawat in urban and rural areas will broaden our perspective on the innovation that has been made in the Sufi tradition in Indonesian Islam. In the following article, specially, we focus on ritual activity of best known urban majelis drikir and shalawat group, the Majelis Nurul Mustafa led by Habib Ḥasan bin Ja'far Assegaf in Jakarta. Both majelis dzikir and shalawat 
groups have exemplified structural and organizational innovation of Sufi tradition in Indonesia. The Majelis Nurul Mustafa was established by a habib, a title to name a descendent of the Prophet Muhammad, Hasan bin Ja'far bin Assegaf (b. 1977). Among people of Jakarta, the habib has been widely known as a leader of the majelis drikir and shalawat group whose participants are mostly teenagers and youths. He is regarded as an Islamic preacher who has been responsible for introducing drikir and reciting shalawat followed with musical instrument (marawis) among urbanites of Jakarta. His picture and the name of his majelis can be easily seen in big posters located along the street of the city before his group conducts drikir and shalawat ritual. The ritual of the majelis which is involved thousands of participants is usually conducted once a week (Saturday night).

The Majelis Nurul Mustafa began its activity from small Islamic lecture circles (halaqah) in the form of majelis taklim under the direction of Habib Hasan in Ciganjur, South Jakarta. After graduated from Pesantren Daruttauhid, Malang, East Java in 1996, he began his career as a wandering preacher in some regions in Jakarta. He held his majelis dzikir in several communities' houses as a venue of drikir and shalawat ritual attended by ten to twenty participants. In the majelis, he invited several youths from the vicinity of the venue to practice dzikir ritual by reciting Rätib al- Atțas, drikir litanies which has been widely popular among Hadrami family in Indonesia. As the number of jamāab was growing, he united several majelis at several houses to one majelis held on Saturday night. He then asked the respected 'ulamā , Habỉb Anis from Solo to give a name for his majelis drikir. Habib Anis named Habib Hasan's majelis with Nurul Mustofa. Currently, Nurul Mustafa has developed as one of the biggest majelis drikir and shalawat groups in Jakarta attended by thousands participants in its weekly ritual on Saturday night ${ }^{4}$. Prior to the ritual, usually the jamā ah are gathered by the coordinator of the majelis according to their regions. They meet in some meeting points and rally to the venue with motors, mini buses and rental cars handling the majelis flags and banner.

\footnotetext{
4 Anonymous. "Menebar Dakwah Dengan Mahabbah." Majalah Kisah Islami Al-Kisah (2011), p.51.
} 


\section{Understanding Majelis Dzikit, Majelis Shalawat and Tarekat Within Indonesian Islam}

For the purpose of this study, it is important to explain particular terms such as majelis shalawat, majelis drikir, and tarekat (Sufi groups) which have been widely used in the study of Indonesian Islamic spirituality for the last two decades. This explanation is necessary particularly to understand the phenomenon of the proliferation of various Islamic spiritual groups within the Indonesian urban Muslim society and the development of studies about Islamic spiritual groups and Sufi traditions in Indonesia.

In urban areas the term majelis dirikir and majelis shalawat are sometimes used together to name a single type group (lit. majelis) that practices Islamic devotional acts to remember God (dbikr Alläh). These recitations include the repetition of the names of God (al-asmä' albusnāa) and phrases derived from Hadith and Quranic verses of supplications but also the recitation of request for blessing for the Prophet. If the majelis categorizes itself as majelis dzikir and majelis shalawat, it always practices the recitation of shalawat to remember and praise the Prophet Muhammad.

Along with the recitation of drikir, shalawat takes the form of the recitation of eulogy books of the Prophet such as Barzanji, ${ }^{5}$ Diba, ${ }^{6}$ and Simt al-Durar ${ }^{7}$ which contain long phrases of blessings of the Prophet and the history of the Prophet. Indonesian Muslim usually called those books as mawlid texts. In the Islamic knowledge, these books can be categorised as Islamic literature works which are known in the classical Islamic nomenclature as al-madäih al-nabawiyah (eulogy of the prophet, sastra pujian kepada Nabi Muhammad). In Indonesia, these books are not only read by majelis dzikir and shalawat but they are also widely popular among other Indonesian Muslims. These books are popularly recited by Indonesian Muslim particularly on the occasion of the

\footnotetext{
5 The author of Barzanji is Syaikh Ja'far al-Barzanjy bin Husein bin Abdul Karim born in Madinah 1690-1766. The title of the book is 'Iqd al-Jawabir but among Indonesian Muslim it is popularly known as Barzanjy which is taken from his name.

${ }^{6}$ The book is written by Al-Imam al-Hafidz al-Muhaddith Abdurrahman bin Ali bin Muhammad al-Syaibani al-Diba'i al-Yamani. The book is widely known among Indonesian Muslim as Mawlid al-Dibä'ï.

7 The book is written by Al-Imam Ali bin Muhammad bin Husayn al-Habshi. This book is widely popular among Indonesian Hadrami Muslim.
} 
commemoration of the birthday of the Prophet Muhammad (Mawlid $a l-N a b \bar{i})$, haw ${ }^{B}$ of the prominent habib or kyai of pesantren, and lifecycle celebrations such as the seventh month of pregnancy, the seventh day of the new born babies, circumcisions, and marriage. However, Indonesian urban Muslims cannot distinguish between the reciting of shalawat and the tradition of reciting madäib. As a result, all of these books are regarded by Indonesian urban Muslim as part of shalawat.

The madä ih books are mostly written in Arabic in a very beautiful and delicate style. Part of the books is chanted in a group in melodious manner, often under the direction of a leader, with reading alternating between soloist and group. This chanting is accompanied by musical instruments consisted of membranophones such as tambourines and drums. In Jakarta and its vicinity, this instrument is called marawis, but in Central and East Java the instrument is called hadrah and in West Javanese Muslims called qasidahan. The chanting of mada'th usually occupies more than half of the ritual of the group. An example of this kind of majelis drikir and majelis shalawat is the Majelis Rasulullah led by Habib Munzir al-Musawwa in Jakarta and the Majelis Nurul Mustafa led by Habīb Hasan bin Ja'far Assegaf in Jakarta, Majelis Ahbaburrasul in Solo led by Habib Syeich (Central Java). On the other hand, if the group calls itself as majelis drikir, it only practices the reciting of drikir formulas, the repetition of the Names of God (al-'asmä' al-husnāa) and supplications taken from Hadith and the Qur'an as commonly practiced by tarekat in order to achieve spiritual perfection and closeness to God. However, these majelis have no structural connection to any tarekat (Sufi order). A well-known example of this kind of majelis dzikir is the Majelis Dzikir Al-Dzikira of Arifin Ilham in Jakarta. This majelis drikir only focuses on reciting drikir in unison led by the leader without reciting al-madä ì al-nabawìyah.

The majelis dz̧bikir and șalawat in urban area are generally initiated by majelis taklim, a non-formal institution initially established as centers of Islamic learning for the community. For the last two decades, majelis taklim have been instrumental in the proliferation of majelis salawat and majelis dzikir especially in urban area. Such majelis taklim functions are

\footnotetext{
${ }^{8}$ Haul literary mean circuit. This term is usually used to name the annual commemoration of the death of respected 'ulamā, kyai, or ḅabīb.
} 
not only as an Islamic learning institution but also as a centre of majelis salawat and majelis dzikir practices. However, not all majelis taklim also provide majelis salawat and majelis dzikir for their participants. There are some majelis taklim that focus only on Islamic learning activities for the community such as Majelis Taklim Kwitang, Jakarta established by Habib Ali bin Abdurrahman al Habsyi (1870-1968), a Hadrami descendent. Not only is The Majelis Taklim Kwitang regarded as the oldest majelis taklim in Jakarta but also it has been considered responsible for the emergence of majelis taklim tradition in Jakarta. Habib Ali's student Kyai Abdullah Syafii established the well-known Majelis Taklim Assyafi'iyah and Kyai Tohir Ramli established Majelis Taklim Attabiriyah. Many other majelis taklim in urban areas are established especially for female participants (jamäab) under the direction of ustädzah (female teacher). Some of these majelis taklim are regularly invited to fill an Islamic lecture program broadcasted live by private and public television stations.?

Another term which is important in the study of Sufi tradition in Indonesian Islam is tarekat (from the Arabic word tariqab). Tarekat is considered the oldest Sufi organizations in Indonesian Islam. This term is widely used in Indonesian Islam to refer to the centres where people practice communal rituals under the guidance of murshid (teacher) In the pesantren tradition, tarekat can be divided into two categories: first, tarekat ammah (general way), that is, orders that encourage the continuous performance of pious acts with good intentions; and second, tarekat khashshah (specific way), that is orders that conduct certain ritual of dzikir under the guidance of murshid (the leader, spiritual teacher). The murshid must be linked through a spiritual genealogy to past murshid in a chain of authorization going back to the Prophet Muhammad. This form of tarekat has some formal conditions: First, in order to become a member of particular tarekat, a disciple must vow of allegiance (bay $\left.{ }^{\prime} a b\right)$ to the master of tarekat ${ }^{10}$. The bay $a b$ is

\footnotetext{
9 Most of private TV stations in Indonesia provide a special program for Islamic lecture with different formats. Usually the program is held in the early morning starting from 5:00 am to 6:00 am. Some of these stations provide a particular space for female preachers with their female jamäah. Female preachers such as Ustadzah Dede Rosyidah Syarifuddin or well known as Mama Dede (Indosiar TV and ANTV), Ustadzah Umi Qurrotu A'yun (MNC TV), Ustadzah Tan Mei Hwa (JTV Surabaya and TV One) are current star among female Indonesian Muslim viewers.
}

10 Zamhari, Rituals of Islamic Spirituality. 
an important requirement of tarekat, since it is considered to bestow the validity on the spiritual journey of the disciples. It is widely held in the tarekat world that following tasawuf path without the guidance of a murshid is like following the path under the guidance of Satan.

Furthermore, some tarekat associated with the Nahdlatul Ulama (NU) organization promote the concept of tarekat mu'tabarah (recognized and legitimate orders). This description applies especially to tarekat under the supervision of the NU. The meaning of this concept is that particular groups of tarekat can be considered as mu'tabarah as long as the teaching of the group must conform with the Islamic Law and the wird or drikir practiced by the group must have a spiritual genealogy going back to the Prophet. As a result of this concept, any groups of tarekat that do not meet the requirements cannot be considered as mu'tabarah and should not be joined with NU organization. The reason to introduce this concept is not only to give strong legitimacy for the tarekat groups and to strengthen the member's faith in their rituals and teachings, but also to make a clearcut distinction between their ritual and other group ritual that $\mathrm{NU}$ considers incompatible with Islamic law.

Even though tarekat, majelis drikir and salawat have a similar objective, which is to purify the self in order to approach God, they differ in some practices. For example, majelis Drikir and salawat do not require their followers to take an oath to the leader of these groups. In other words, people are able to join and practice their salawat and Drikir without taking committing themselves exclusively to the leaders. As a result, people can join one particular majelis salawat and Drikir group, while at the same time also become a member of another majelis salawat and Drikir group, something which is generally not possible for members of tarekat in Java.

Tarekat, majelis Drikir and shalawat also differ in the Drikir recited in the ritual. The Drikir text recited in majelis drikir and salawat is generally created by their leader or taken from drikir formula taught by the Prophet or widely used by prominent 'ulamà. In contrast, dzikir formula recited in the tarekat group are believed to have been transmitted from the teacher's teacher and so on through a series of unbroken links back to and the Prophet. The followers of tarekat are obliged to recite drikir formula every day, usually after the five obligatory daily times prayer. Unlike tarekat, the members of majelis salawat and dzikir are allowed to practice the group's drikir 
intermittently without any sanction, even though the leader of the groups recommended that their followers practice the chosen diqikir continually.

Distinguishing those terms clearly will give a clear sense of the variations in Islamic ritual groups that have developed within Indonesian Muslim society over the last few decades. In addition, distinctions will help people understand the innovations that have been made in the Sufi practices and organizations in Indonesia of late.

\section{General Features of Majelis Taklim}

Even though scholars have different view on the origin of pesantren in Indonesia, they have agreed that pesantren is the oldest system of Islamic learning and education in Indonesia. With the emergence of a modern Islamic education schools recently, pesantren has survived and maintained its tradition and at the same time it has accommodated some modern education system. In this regards, pesantren should compete with modern secular education institution. In Indonesia, we can find a various pesantren which generally function as a centre of learning Islam as well as a centre of Sufism and majelis Drikir. Likewise, scholars cannot exactly know when majelis taklim term was initially introduced in Indonesian Muslim community. The majelis taklim is a term to denote an institution in which a group of Indonesian Muslim communities not only conduct learning of Islam and Islamic preaching activities but also conduct majelis dzikir and salawat. In the last ten years majelis taklim with its variety has proliferated particularly in urban area.

The basic elements of majelis taklim are the venue for activities (Arabic, majelis), the leader (can be a kyai, ustad, or habib), and the participants $\left(j a m a a^{\prime} a b\right)$. Majelis taklim does not provide a dormitory for the participants (jamaiab) of the majelis because they only attend the program of majelis taklim and return to their home when the program concludes. However, a few majelis taklim such as the Majelis Rasūlullah and the Majelis Nurul Mustafa located in Jakarta provide a simple house as a residence for their technical staffs and a mushalla (a small praying venue) which is used for praying, teaching activity and the ritual of drikir and shalawat. In some cases senior staffs live in the house which also functions as the office of the majelis. One of the rooms in the house is usually provided for the leader which is used as his private room and office. Even though the leader of the majelis has a family private house, he usually lives in the house everyday together 
with his staffs and only visits his family twice a month. The residence is usually owned by the leader or is rented by the leader for the center for the activities of the majelis.

Similar to pesantren, a mosque is the centre of Islamic rituals and activities for majelis taklim. However, unlike pesantren, majelis taklim do not establish their own mosque as the centre of their activities. The majelis taklim often make use of a community's mosque as the venue of their regular activities. Even, similar to pesantren, some big majelis taklim in Jakarta originate from those mosques. The reason of using a community's mosque as the venue of majelis taklim activities is that it is difficult to find big venues in urban area that can contain thousands of jamäah (participants). ${ }^{11}$ Such large majelis taklim occasionally make use of a city park or football stadium as a venue of big event which involves participants from many regions. However, to make use of a football stadium and city park, the majelis taklim has to pay a rental fee to the city administration, while to make use of mosques, the majelis taklim do not have to pay a rental fee. Therefore, every majelis taklim makes use of particular mosque in urban area as important venue for its regular activities. Each majelis taklim in urban area, for instance, usually makes use of four of five mosques and conducts its ritual in those mosques weekly. However, some majelis taklim in Jakarta establish their own building as the venue of the majelis' activity such as a big hall which is usually located close to the residence of the leader.

In terms of learning process, majelis taklim conduct Islamic learning for community by referring to classical Islamic books (kitab kuning). Majelis taklim do not use any specific Islamic books or books categorized as mu'tabarah. Majelis taklim use any Islamic books, either classical ones or modern ones, as long as they are relevant to the objective of the majelis and the interest of the leader of majelis. For instance, in the formative period of Majelis Dzikir and șalawat Majelis Rasullullah in Jakarta, the leader of this majelis taught Islamic Jurisprudence (fikib) to his participants. When the leader thought that the participants were not enthusiastic and no longer needed Islamic Jurisprudence subjects, he then changed the subject to the ethics of the prophet taken from prominent Hadith books such as Bukhari Muslim. ${ }^{12}$ On the other hand, the leader of Majelis Nurul Mustofa

${ }^{11}$ Interview with the deputy of leader of Majelis Rasulullah, Habib Ahmad on June, 2011

12 Interview with the Deputy of Majelis on June 2011 
prefers to teach the story of Muslim saints of Hadramaut (hagiography books), Yemen, and the book on Khasa'is Ummat Rasül Alläh (The Distinctiveness of the Followers of the Prophet), to his followers. The reason of the leader teaches the story of Muslim saints is to introduce his jamāah to those saints of God who have been able to obtain a highest spiritual stage in their life. In addition, it is expected that those saints of God (awliyal, Allah) who are the descendants of the prophet can be used as a means for the jamäah (followers) to know the Prophet, whose example is the most important guidance to correct conduct and the achievement of states of grace. ${ }^{13}$

The participants of the majelis taklim are called jamäah (followers). In order to be a follower or participants of majelis taklim, one does not need to register formally and pay membership fee. There is no membership in a majelis taklim. People can be regarded as the followers of majelis taklim as long as they attend drikir and shalawat ritual of majelis taklim and participate in the activity of the majelis regularly. Moreover, people can voluntary join one majelis taklim while also joining another majelis taklim. People from different age are able to join the group regardless of their gender. However, recently some majelis taklim have been established especially for female participants, while other majelis taklim still include both female and male participants.

In term of schedule, majelis taklim conduct its activities in the flexible time. Majelis taklim conduct its activity any time according to the consent of the followers and the availability of the leaders. Sometimes, the activity of drikir and shalawat is held in the morning and evening. However, most of majelis taklim in urban areas conduct its drikir and shalawat ritual in the evening after 'isha' prayer until midnight.

The leader is important element both in pesantren and majelis taklim. The leader of majelis taklim can be an independent kyai, or habib. In the past, the title of kyai was commonly inherited, especially kyai who runs pesantren. However, currently the concept of kyai in Java has changed. The title of kyai is no longer inherited genealogically. One can be a kyai as long as the member of society recognize him as a kyai by virtue of his mastering higher Islamic knowledge and his influential role in Islamic preaching among community. Therefore, it is not

\footnotetext{
13 Interview with Ustad Riziq, a preacher of the Majelis Dzikir and Shalawat Nurul Mustafa on September 2011
} 
unusual that some prominent kyai in Java do not come from a kyai family and they do not run a pesantren. An example of this kyai is the late Kyai Zainuddin MZ, a famous Indonesian preacher well known as Dai Sejuta Ummat (preacher of millions people). The title of kyai is not similar to that of priest, monk and cleric as in Christian or in Buddhist tradition. There is no a particular Muslim institution in Indonesia that approves and authorize kyai. Similarly, there is no Muslim organization that can remove kyai from his position. Currently, it is not unusual for big pesantren to have more than one kyai.

In contrast to the term kyai, habīb is a title given only to Hadrami people who are considered to be a descendant of the Prophet. In fact, the term habib is a name of social stratum to denote the social stratification system in Hadramawt society in Yemen. The saada or babib ${ }^{14}$ (pl. haba'ib), sayyid ${ }^{15}$ or syed are the descendants of the Prophet Muhammad and the top social strata among Hadramawt society. Although they lack of military power, the sadah are highly respected as arbitrators in tribal conflict and in charge of religious education. The sädah is followed by masyayikh, descendants of respected religious scholars and it is followed by qabail which is lower than masyayikh but still to be viewed as part of the second strata because most of them have common descent with the masyayikh. The lowest in the Hadramawt society is masäkin, consisting of different group of artisans, servants and peasants. At the bottom of social rank is the abd, the slaves. ${ }^{16}$ Despite complicated strata among Hadrami, Indonesian Muslim usually call habib to any Indonesian Hadrami descendents regardless of their social strata as long as they are equipped with higher Islamic knowledge and also are active in the preaching of Islam among community.

\section{The Majelis Dzikir and Șalawat Nurul Mustafa}

In addition to pesantren, another institution which can also be considered as another venue that can maintain Islamic tradition among urbanites has been majelis taklim. A part from tarekat, pesantren also

\footnotetext{
${ }^{14}$ Habī means 'beloved' in Arabic.

15 Sayyid means 'lord in Arabic.

${ }^{16}$ Frode F. Jacobsen, Hadrami Arabs in Present-day Indonesia: An Indonesia-oriented group with an Arab signature (London and New York: Routledge Taylor and Francis Group, 2009), p.8.
} 
becomes the home for majelis drikir and majelis shalawat. Likewise, majelis taklim in urban area has provided a venue to conduct majelis shalawat and majelis drikir. The following paragraphs will describe the comparison between the Majelis Shalawat Wahidiyah which is initiated by Pesantren Kedunglo, Kediri and the Majelis Nurul Mustafa which arises from majelis taklim located in Jakarta.

\section{The Organization}

Gilsenan, in his classical work on Saints and Sufi in Modern Egypt, used term organization and association to describe the structure of Sufi orders (tarekat). An organization emphasizes 'a high degree of stratification on the basis of differential expertise and/or efficiency.' An organization is also characterized by 'greater structural recognition of functional inequality and formal control based on hierarchy of authority statuses. In contrast, an association is characterized by 'looseness of structure with minimal development of a status hierarchy. Individual commitment in an association is also voluntary and egalitarian. Moreover, the appointment of officials is based on administrative convenience. He concluded that the majority of Sufi orders in Egypt could be placed on a continuum between organization and association. ${ }^{17}$

However, Gilsenan's typology cannot be easily applied to describe the structure of majelis drikir and shalawat in Indonesia. Unlike Sufi orders in Indonesia which have hierarchical positions such as master (murshid), vice master (khalifah), and disciples (murid), in majelis drikir both in pesantren and majelis taklim, these positions are not recognized. Both groups only recognize a single position of leader who is regarded as a central figure in both majelis. The figure of kyai and habib is instrumental in the organization's structure of the majelis.

Unlike other Sufi groups in Indonesia, the Majelis Nurul Mustafa does not have local branches. In order to run its activities, the majelis does not establish hierarchical organization from the higher level of organization of the capital city to the lower level of organization in villages. Instead, the leader of majelis simply chooses several staffs and technical assistants responsible for particular tasks in the central office of the majelis. The selection of staff and technical assistants is believed to be based on spiritual vision of the leader. The leader is believed to

${ }^{17}$ Michael Gilsenan, Saint and Sufi in Modern Egypt: An Essay in the Sociology of Religion (Oxford: The Clarendon Press, 1973), pp. 65-66. 
have a spiritual power to choose who the right person to be his staff is. These elected assistants and officials are instrumental in preparing activities of the majelis under the instruction of the leader of the majelis. They are monthly paid by the majelis taken from treasury of the majelis. A residence is provided by the leader for particular staffs and technical assistants. This residence functioned not only as a central headquarter of the majelis but also as a venue for the ritual and learning of Islam for small number of the followers. Instead of living with his family, the leader of the majelis mostly lives in the residence together with his staffs and teachers. To organize a big ritual event in the city, the staffs are helped with coordinators (kordinator lapangan) located in every region of the city. The number of coordinators is more than hundreds in all regions of Jakarta. These coordinators voluntarily help the majelis to organize followers of the majelis in their areas to attend and prepare any major events held by the majelis in the city. In order to hold a ritual event outside Jakarta, local committee will be responsible for the preparation of the event with supervision of the majelis.

Nurul Mustafa is established in the form of yayasan (foundation) and it is registered in the Ministry of Law of the Republic of Indonesia. With this format, Nurul Mustafa must abide by the law of foundation stipulated by Indonesian government. As a yayasan, Nurul Mustafa has bureaucratic structure such as the head of yayasan, the deputy of yayasan, and treasurer. However, the majelis does not have departments or divisions which are responsible to implement organizational tasks. It seems that this foundation can be categorized as a family foundation, because most of the boards members of the foundation are the relatives of the leader of the majelis. Like in the leadership of tarekat, the concept of wakill, na'ib (deputy) is also known in the Majelis Nurul Mustafa. The wakil of leader is needed in the majelis particularly when the leader cannot lead drikir service for particular reason. Usually, Habib Hasan, the leader of the majelis, asks his brother to replace himself if he is absent on the divikir and shalawat ritual.

\section{The Rituals}

Majelis Drikir and shalawat of majelis taklim focus on reciting ritual of particular dzikir and shalawat. The Majelis Shalawat and Dzikir Nurul Mustafa focuses their activity on reciting shalawat and drikir ritual. However, the shalawat which is taken from books categorized as almada'ih al-nabawiyah or 'mawlid' book is recited in the form of musical style accompanied by traditional music called marawis. This group 
recites one of al-madäith al-nabawiyah books called Simt al-Durar. The recitation of these books occupies the whole ritual of this group. Even though there is no particular courtesy during the ritual, one of teachers of this group stresses the importance of good intention and comprehension of every single text of the book so that people are able to achieve blessing (barakah). After setting good intention, then people should recite the opening chapter of the Qur'an (al-Fatihah) conveyed to the author of the book and our parents so that we can feel the blessing of reciting the book. The group prefers to use Simt al-Durar as part of the ritual due to the fact that the author of this book is one of the descendants of the Prophet, while many other books are written by non- descendant of the Prophet Muhammad. In addition, the group also recites drikir formula of Ratib al-Haddad written by the famous Muslim scholars from Hadramaut, al-Habỉb `Abdullah bin `Alawi alHaddad (1044-1132 H) ${ }^{18}$ as well as Ratib al-Attas. The leader of the majelis does not recommend his followers to follow particular courtesy prior to the ritual of reciting shalawat. However, during the recitation of the salawa, the Prophet is believed to be present in the ritual. As a result, the followers of the majelis are strongly urged to stand up to respect the Prophet. As happened in most mawlid ritual in the Hadrami family in Indonesia, the ritual of reciting drikir and shalawat in the majelis is accompanied with burning aromatic incense which release fragrant smoke. The incense burning place is put in front of the majelis close to the leader of the ritual. The aroma of incense as believed by one of teachers of the majelis will be the witness for those who practice in the shalawat and drikir ritual in the hereafter.

The ritual of Nurul Mustafa is conducted on the basis of a set of weekly schedule. The ritual of this majelis conducted in different places in Jakarta is led directly by the leader of this group, Habib Hasan bin Ja'far Assegaf and his three other brothers, Habib Abdullah bin Ja'far Assegaf, Habib Mustafa bin Ja'far Assegaf, Habib Qasim Sami bin Ja'far Assegaf. Habīb Hasan bin Ja'far Assegaf, the leader of the majelis, usually leads the a big ritual of this majelis conducted on Saturday night in different places in Jakarta as well as a ritual held in the central office of the majelis, ${ }^{19}$ while other rituals held in other days are respectively

18 Yunus Ali Al-Muhdhor, Mengenal Lebih Dekat al-Habib Abdullah bin Alawi al-Haddad: Kisab Hidup, Tutur Katanya dan Tarekatnya (Surabaya: Cahaya Ilmu Publisher, 2010), p.2.

${ }^{19}$ Usually the followers and staffs of the majelis called their office as istana (the palace). 
under the direction of his three brothers. Habib Hasan, the leader, divides location of the majelis ritual in Jakarta into three areas: West Jakarta is led by Habib Mustafah bin Ja'far, East Jakarta is under the direction of Habib Qasim Sami, and South Jakarta led by Habib Abdullah bin Ja'far. These three areas will gather collectively in the majelis ritual on Saturday night.

The leader of the groups usually delivers Islamic lecture on particular themes during the ritual held by the majelis. The topic of the Islamic lecture is chosen by the leader. The theme of the lecture in the Nurul Mustafa includes the stories of Muslim saints (awliy $\bar{a}$ ), the story about the life of the Prophet, the importance of loving the Prophet and his family and the character of the Prophet. In the ritual held every Saturday night, the leader of Majelis Nurul Mustofa invites several Muslim scholars ('ulamā) to deliver a small speech after reciting dzikikir and shalawat.

The relationship between the leader of Nurul Mustafa and the followers either during the ritual or outside the ritual is of important aspect of those groups. The relationship is not like the strong masterdisciple (murshid-murid) relationship in many Sufi orders. The relationship is based on common relations practiced in teacher-student relations in the Islamic learning tradition, while the relationship between murid and murshid in Sufi orders is strongly based on a complex set of adab (comportment) as well as sanctions. The late Kyai Usman Ishaqi, the murshid of Qadiriyah wa Naqshabandiyah order from Surabaya, mentioned the adab by which the murid should completely respect their murshid. He puts it this way:

You should respect your syaikh and believe outwardly (zähir) and inwardly (batin), without the help of the syaikh, your objective will never be obtained. You should not complain about what the shaykh has done, even though the shaykh may have done something which is unlawful in appereance. Instead, avoiding negative prejudice against the shaykh, people should be convinced that what the shaykh done is clearly based on God's orders. If you still do not understand this, you should think that this is because of your lack of your knowledge in understanding the essence of the matter...In all your life matters either in their totality or in their details, in devotional aspect or cultural aspects, you should abandon your own choice because your shaykh has chosen for you...Y You should not talk in front of your 
shaykh. When he asks you, instead of answering too long, you must answer the question precisely. This partly because speaking too much in front of the shaykh will eliminate his veneration. Therefore, the excellent adab of a murid toward his shaykh is that you should be silent, quiet, and pay attention to what the shaykh says and do that which contribute to welfare. ${ }^{20}$

This adab (comportment) is relevant to the famous expression in the Sufi tradition, Be with your shaykh like the corpse in the hands of the washer; he turns it over as he wishes and it is obedient. ${ }^{21}$ This long adab is extremely stressed in a Sufi tradition, either by murshid or his khalifah, especially on the occasion of initiation. In contrast, even though the jamäab of the majelis do not follows such as adab, they still pay respect to their leader and consider their leader as the person who is able to guide them spiritually.

\section{Financial Support}

In order to run and support activities of the majelis, Nurul Mustafa seeks and draws funding resources such as cooperatives, shops, financial government assistance as well as financial assistance from followers. The Majelis Dzikir and Shalawat Nurul Mustafa draws funding from the followers through conventional mechanism. For instance, the majelis collect funds from the jama a ab during the ritual by providing collection boxes. These boxes are distributed with the crews of the majelis among followers who attend the ritual. They are strongly recommended to give some money for the jamāah. Furthermore, the majelis also seeks funds resources from selling merchandise of the majelis such as the picture of the habib, the majelis' jacket uniform and DVD's on the ritual of the majelis, charging parking fees, and charging electricity fees for street traders during the ritual, renting sound system, lights, and a stage. Sometimes the Majelis Nurul Mustafa is invited by the jama "ab to conduct drikir and shalawat ritual in their region. If this is the case, the jama $a b$ must cover all expenses of the ritual including sound system rental, lights, and a stage catered by the majelis'

\footnotetext{
${ }^{20}$ Muhammad Usman Al-Ishaqi, Al-Khulashah al-Wafiyyah Fi al-Adab wa Kayfiyat alDhikir Inda al-Sadat al-Qadiriyyah wa al-Naqshabandiyah (Surabaya: Al-Fitrah, n.d), pp. 56.

${ }^{21}$ J. Spencer Trimingham, The Sufi Orders in Islam (New York: Oxford University Press, 1973), p. 187.
} 
appliances. Moreover, the majelis also conducts annual program of visiting the sacred tombs of awliy $\bar{a}$, throughout Jawa led by the leader of the majelis. In order to join this program, the jama ab should pay particular amount of money for a bus ticket rented by the majelis. All of these funds are being channeled for the activity of the majelis.

\section{Memberships}

As happened in many other Sufi groups, the exact number of members (jam $\left.\bar{a}^{\prime} a b\right)$ and their social background are not easy to establish because the Majelis Dzikir and Shalawat Nurul Mustafa keeps no official records and the recruitment of new followers is not officially recorded. The member of these groups includes not only elderly men and women but also younger people and children. However, the number of teenager exceeds the number of other group of age.

To become participants of those majelis drikir and shalawat groups, people do not need to take an oath or initiation (bay ab) to the leader or his representative as in the case of member of tarekat. In other words, the mode of entry is voluntary, so people can practice the ritual and recite the drikir and shalawat without asking direct permission to the leader. Moreover, those groups do not ask an exclusive commitment on the part of their members. Therefore, people can voluntarily take part in the activities of those groups while also being participants in other groups. As argued by Abdurrahman, coordinator of the Majelis Nurul Mustafa, the jamāah of the majelis are allowed to participate with other majelis to fulfill the obedience of seeking knowledge as Muslims. Seeking Islamic religious knowledge for him can be obtained from different sources and different majelis as long as they are relevant to the teaching of Islam. However, Abdurahaman, the coordinator of the Majelis, pointed out that people must find a single spiritual teacher who is able to guide them in this world and in the hereafter. In other words, the jamáah of the Majelis Nurul Mustafa are not allowed to choose more than one spiritual teacher for their spiritual life. In this sense, if they have decided to choose the habib of Nurul Mustafa as their spiritual teacher, they are not permitted to follow other $h a b \bar{a}^{-} i b$ as their spiritual teacher. He says as follows:

'People can join the Majelis Nurul Mustafa and practice the ritual of other majelis. They have a freedom to join other majelis as part of their obedience to seek Islamic knowledge 
from any various resources. However if they seek a spiritual master for themselves they have to choose only one particular spiritual master.' 22

It is interesting to note here that the Majelis Nurul Mustafa allows non-Muslim to participate in the ritual without requiring them to convert to Islam. In contrast to majelis drikir and shalawat, the Sufi orders (tarekat) ask their member to take avow of allegiance to their shaykh or murshid, before they can recite a special dzikir and more ahzzab, a special wird created by Sufi or Muslim scholars. ${ }^{23}$ Even, Sufi groups such as Hamidiyah Shadiliya ${ }^{24}$ and Tijaniyah Sufi groups have demanded an exclusive commitment from their member. For instance, people who join Tijaniyah are expected to abandon their commitment to other Sufi groups.

The Majelis Dzikir and Shalawat Nurul Mustafa also does not require a particular mode of recruitment. People can be regarded as part of jamaiah of the majelis, if they would attend and participate in the ritual of the majelis regularly. In this respect, the continuity (istiqamah) of attending and participating is extremely stressed in the majelis. For instance, in every dzikir ritual held by the jamäah, the leader of the group continuously stresses the importance of attending and practicing the diqkir and shalawat ritual for his jamäah. For the leader of Nurul Mustafa, continuity is extremely important because it will generate a lot of blessings of God for the improvement of peoples' spiritual life. Quoting a popular proverb in Sufi tradition, he pointed out that continuity is much better than a thousand of miracles (karamah).

In order to keep the jama'ah involve on the practice of dzikir and shalawat held by the majelis on regular basis, the leader of this group tries to find particular ways to increase their interest of attending the majelis ritual. One of the ways is by introducing and creating new melodies in the reciting of shalawat accompanied by entertainingly musical instruments as well as creating new songs for the ritual. According to Ustadz Jamal, who is a vocalist of the majelis, songs which he usually sings during the ritual are written by the leader of the majelis. He and the leader of the majelis regularly discuss the text of the

\footnotetext{
22 Interview with Abdurrahman, the coordinator of the ritual, November 2011.

23 Trimingham, The Sufi Orders, p. 187.

${ }^{24}$ Gilsenan, Saint and Sufi in Modern Egypt, p. 94.
} 
song and make its melody. The shalawat song is effective to attract the interest of the jama $a b$ which is mostly dominated by teenagers and youngster to attend the ritual. In addition, in order to attract the jamaiah to attend the majelis, the majelis also invites celebrities, TV stars, and public figures to attend the ritual and give them the opportunity to make a short talk before the ritual of diqikir and shalawat begin. Internet and SMS from mobile phone are another important means to keep the jamā $a b$ informed and involved in the activity of the majelis. The majelis sets up a website of the majelis (http://nurulmusthofa.org) and facebook which mainly contain the activity of the majelis, a weekly schedule of the ritual, stream video live taken from the weekly ritual, pictures of the haba'ib and the transcript of the leader's speech in the ritual of the majelis.

Moreover, to attract the jamäah attending to the majelis, after Drikir ritual held by the group in headquarter of the majelis, the habīb also provides simple dinner. The majelis distributes a big plate with full of rice and meat accompanied by a cup of mineral water. One big plate is usually provided for three or four jamāa $a$. Another salient strategy of this majelis to attract new participants is by introducing the leader of this jama $a b$ as the descendent of the Prophet. This strategy is proven to be effective to improve the authority of the majelis among other majelis and the interest of jamä ah to join the majelis. As a result, they become interested in keeping involved in the jama ah on regular basis because of the figure of the habib. One of the jamāa $a b$ explained why he is interested in joining the group:

'I joined and practice the ritual of dizikir and shalawat of Nurul Mustafa because of the figure of the majelis' leader. He is a habib, the great grandson of the Prophet. Even though I have never met directly to the Prophet, of course I am not able to meet the Prophet by myself, at least I can meet His great grandson (cucu). For me, this is the same. I am not able to love the Prophet, but I am able to love the habib. I hope the way I love the babīb, the Prophet's grandson, is similar to the way the habīb loves his grandfather.' ${ }^{25}$

${ }^{25}$ Interview with Faiz, the follower of the majelis on July 2011. 


\section{The Authority of the Leader}

The head of the group is important in the Majelis Dzikir and Shalawat Nurul Mustafa. The head of the group has important role not only in developing the majelis but also in attracting the followers of the majelis. In this respect, authority of the leader is significant in the establishment of the majelis dzikir or shalawat. Most of majelis drikir and shalawat are established on the basis of charisma of the leader. The authority of the head of the Majelis Dzikir and Shalawat of Nurul Mustafa is built on the basis of the leadership of habib figure. Habib is a title given to those who are considered as male descendent of the Prophet Muhammad, while sharifah is a title given to female descendents of the Prophet. The concept of the habīb and sharifah has been well preserved particularly in the Indonesian Hadrami families. The Hadrami family categorized as sayyid usually has the line of family tree (silsilah) which is traced back to the Prophet. In order to preserve the purity of their Arab family, they only get married with those from Arab family.

Like many other Hadrami families in Indonesia, the leader of the Majelis Nurul Mustafa put his genealogical family tree in his mushalla (a small venue for praying) so that the jama $a b$ can clearly read and see his descendant up to the Prophet. Currently, among Indonesian Muslims, the title of habīi is given only to those Indonesian Arab families who are not only the descendent of the Prophet but also those who are equipped with the higher Islamic knowledge and the highest station of Sufi practices. The habib believes that as haba'ib are the descendents of the Prophet, they have a potential of spiritual power (bashirab) derived from their grandfather (jadd) ${ }^{26}$ (the Prophet Muhammad), which is easily used to improve their consciousness to God. ${ }^{27}$

Therefore, with his privilege, as the leader of majelis drikir and shalawat, he regard himself responsible to introduce Muslim to the Prophet, as he is part of the family of the Prophet who has genealogical connection with those who have previously achieved the highest station of Sufi practices. In this regard, tawassul (seeking a means) through these renowned habä'ib (sing. habīib) and awliyà' (the saints of God) is extremely stressed in the majelis. Habib Hasan

\footnotetext{
${ }^{26}$ ' $i d$ ' meaning grandfather, is an Arabic work which is usually used by Indonesian babaib to call the Prophet Muhammad as their grandfather.

${ }^{27}$ Interview with Habib Hasan bin Jakfar Assegaf, November 2011.
} 
explains the importance of tawassul as follows, 'Love of awliya' cannot only help us in the hereafter but also lead to love the Prophet and God.' On the weekly ritual, he also says, 'We must give respect to the family of the Prophet Muhammad (dhurriyat al-rasū) and the Saints of God. Our heart must not forget the Prophet. Respect His grandsons, in order to make them happy.' 'The special status of the abl al-bayt is found in two verses in the Qur'an. The first verse is 33:33: 'God only whishes to remove all filth from you, people of the house (abl al-bayt), and to purify you completely.' Another verse commanding Muslim to respect love the Prophet's family (abl al-bayt) is 42:23: 'I do not ask you for reward (for delivering the revelation), except the love of those who are near of kin.' There are numerous Hadith (Prophet tradition) which extol the status of abl al-bayt and command Muslims to love them. The example of the Hadith is 'whoever prays a prayer in which he does not bless me and my family, it will not be accepted.' Another Hadith is 'the people of my house are like the Ark of Noah, whoever rides is saved, and whoever stays behind is shaken by hellfire.' Even though there are several verses and Hadith commanding to love abl al-bayt, the habib never cited during his speech. He just stressed the importance of respect the Prophet's families and extol the status of them.

Moreover, the authority of the leader of the majelis is also based on the connection of the habīb with that of habä'ib or 'ulamā in Hadramawt, especially in the region of Tarim. Historically, Hadramawt has been considered as one of the origin of Islam in Malay-Indonesian Archipelago. ${ }^{28}$ The role of the Hadrami in the process of Islamization in the region has probably been substantial. With this historical position it is no doubt that Hadrami has been important among Indonesian Muslims religiously. Even, it is widely held among Indonesian baba'ib that most of the Nine Saints (Wali Songo), the preachers of Islam, in the history of Islamization in the archipelago are Hadrami or have Hadrami descendants.

Among habä'ib in Indonesia in particular and Indonesian Muslims in general the region of Tarim has been well known as a place where most of renowned haba'ib and the saints of God live and a lot of shrines of awliya' become the object visitation of Muslims from

28 Azyumardi Azra, Jaringan Ulamā Timur Tengah dan Kepulauan Nusantara Abad XVII dan XVIII (Bandung: Mizan, 1999), p.28. 
different places in the world. In addition to Haramain, Hadramawt is another destination for Indonesian Muslims who seek Islamic knowledge, visit the sacred sites and the centre for Sufi heritage. Therefore, with this important position of Hadramut religiously, the babäib of Indonesia try to link their connection with the haba'ib and the sacred places in Hadramawt. For instance, the leader of the majelis makes regular visit to Tarim and meet its haba'ib and 'ulamä' which are believed to be the saints of God. In addition, the majelis also invites the 'ulamā' and habä'ib from Hadramawt (Tarim) to attend and lead the annual ritual of the majelis. Inviting the habà'ib and 'ulamā' of Tarim without doubt can increase not only the authority of the majelis but also the leader of the majelis. The presence of the ulamā from Tarim also makes the jama ah believe that the ritual they practice is closely connected to the similar tradition widely held by 'ulamā' in Tarim to whom their leader has continuously told the story about their life, virtues and their Sufi practices. The importance of Tarim for this majelis has been told by one of the teachers of the majelis as is follows:

Without Tarim, Indonesia may be still in the age of dark. Tarim is a place where most saints of God grow. All the Nine Saints are from the descendent of Prophet of Tarim...Tarim can be described as the centre of electricity which illuminates to different places of the world. I have studied at Tarim for four and half years because of the babī asked me to study there. When I studied there I felt that the habib was presence. For me, although the habīb never studied in Hadramawt, he has obtained the secret of Hadramawt's 'ulamā'. I have met many respected 'ulamā and studied Islamic knowledge from them. I have tested Tarim's salt. All of them have the same virtues as the Habib Hasan. One day I felt very sad, because a lot of problems that I faced such as the delay of pocket money from my parent and homesick. One day I visited one of 'ulamā' of Tarim and he just rubbed my head and prayed for me then suddenly I felt happy. ${ }^{29}$

\section{Conclusion}

Sufi tradition in Indonesia has been experiencing innovations socially and structurally since the last two decades. These innovations

${ }^{29}$ Interview with Ustad Rizq, January 2012. 
are well exemplified by some majelis drikir and shalawat groups in Indonesia, like Nurul Mustafa. This group has represented a new Sufi group that arises out of tarekat group, a group that has been considered as 'official institution' in implementing Sufism. As I argued elsewhere, even though the group cannot be categorized as tarekat, it strongly emphasizes the drikir and shalawat rituals and the teaching of Sufism which are also stressed in the tarekat traditions in Indonesia.

As a majelis drikir and shalawat, the group has introduced Sufi teachings in their rituals. However, unlike a tarekat group, the Majelis Nurul Mustafa differs on their emphasizing on Sufism. The Majelis Nurul Mustafa which has its strong basis in urban society and arises from urban majelis taklim introduces Sufi teaching to its jamä ah as the complementary of its activity. For instance, Sufi themes are given by this majelis as part of other themes including ethics (akblaq), Islamic jurisprudence $(f i q h)$, the hagiography of saints of God, the story of the prophet (al-sirah al-nabawiyah), and the virtues of habä'ib. In addition, the Majelis Nurul Mustafa selectively uses Sufi teachings and texts of $d$ rikir and shalawat only from sources which are mostly taken from the tradition of Sufism practiced by Hadrami 'ulamā' or ḥabà ì

The Majelis Dzikir and Shalawat Nurul Mustafa whose jamāah are mostly urban teenagers and youths uses popular methods to attract the interest of those groups to attend its ritual. The example of this popular method is by introducing membranophones or rebana music following the reciting of shalawat. New melodies which are familiar to the ear of teenagers are also introduced in the recitation of shalawat. The method is proven to be effective to attract the interest of youth and teenagers attending the majelis.

The Majelis Dzikir and Shalawat Nurul Mustafa has contributed to the development of pluralism idea among Indonesian Muslim. This can be seen from the fact that the majelis allows non-Muslims to practice and join the ritual without asking them to convert to Islam. It is undoubted that not all Muslims agree with this idea. furthermore, several Muslim groups considered pluralism as a non-Islamic teaching that can be categorized bid'ah. In fact, the ideas of pluralism are necessarily needed for improving a peaceful life in Indonesia with its pluralistic culture and religions. Introducing the teaching of pluralism in the religious ritual will help to create a civilized society. In addition, this group also play important role in denounce the idea of radicalism which have proliferated in urban area after the reformation era. Sufism 
with its tolerant and ethics introduced by these groups is able to counter the radical teachings promoted by the so called radical Islam groups. []

\section{References}

\section{Books and Articles}

Anonymous. "Menebar Dakwah Dengan Mahabbah." Majalah Kisah Islami Al-Kisah, 2011: pp. 49-55.

Al-Muhdhor, Yunus Ali. Mengenal Lebih Dekat al-Habib Abdullah bin Alawi al-Haddad: Kisab Hidup, Tutur Katanya dan Tarekatnya. Surabaya: Cahaya Ilmu Publisher,2010.

Azra, Azyumardi. Jaringan 'ulamā Timur Tengab dan Kepulauan Nusantara Abad XVII dan XVIII. Bandung: Mizan, 1999.

Böttcher, Annabelle. "Religious Authority in Transnational Sufi Networks: Syaikh Nazhim Al-Qubrusi Al-Haqqani alNaqsahbandi." in Gudrun Kramer and Sabine Schimidtke (eds.). Speaking for Islam: Religious Authority in Muslim Societies. Leiden: Brill, 2006.

Dhofier, Zamakhsari. The Pesantren Tradition; The Role of the Kyai in the Maintenance of Traditional Islam in Java. Arizona: Program for Southeast Asian Studies, Arizona State University, 1999.

Jacobsen, Frode F. Hadrami Arabs in Present-day Indonesia: An Indonesiaoriented group with an Arab signature. London and New York: Routledge Taylor and Francis Group, 2009.

Howell, Julia Day. "Modernity and Islamic Spirituality in Indonesia's new Sufi Networks." Martin Van Bruinessen and Julia Day Howell (eds). Sufism and 'The Modern' in Islam. New York and London: IB Tauris, 2007.

-------. "Sufism and the Indonesian Islamic Revival." The Journal of Asian Studies, 60, 3 (2001): pp.701-729.

Howell, Julia Day, M.A. Subandi, and Peter L. Nelson. "New Faces of Indonesian Sufism: A Demographic Profile of Tarekat Qadiriyah-Naqshabandiah, Pesantren Suralaya in 1990s." Review of Indonesian and Malaysian Affairs, 35, 2 (2001): pp.33-60. 
Arif Zamhari

Al-Ishaqi, Muhammad Usman. Al-Khulashah al-Wafiyyah Fi al-Adab wa Kayfiyat al-Drikir Inda al-Sadat al-Qadiriyyah wa al-Naqshabandiyah. Surabaya: Al-Fitrah, n.d.

Gilsenan, Michael. Saint and Sufi in Modern Egypt: An Essay in the Sociology of Religion. Oxford: The Clarendon Press, 1973.

Trimingham, J, Spencer. The Sufi Orders in Islam. New York: Oxford University Press, 1973.

Zamhari, Arif. Rituals of Islamic Spirituality: A Study of Majelis Dhikr Groups in East Java. Canberra: ANU E-press, 2010. 